\section{Personal view: security sector health systems and global health}

\author{
Martin Bricknell $\odot$,' $\mathbf{S}$ Horne $\oplus^{1,2}$
}

\begin{abstract}
In many countries the security sector is a major contributor to the healthcare system. The role and transformation of a state's security health system within the universal health coverage is important, in that it sits at the interface of the United Nations Sustainable Development Goals 3 (ensure healthy lives and promote well-being) and 16 (promote just, peaceful and inclusive societies). The paper describes the breadth of the security sector and outlines the potential beneficiaries, clinical services and macro-organisation of a security sector health system from the perspective of its contribution to wider government health services and crisis response. It examines the characteristics of the security sector compared with other providers of health services, including those generic to the sector and unique to a given service. Understanding civil-security relationships is a critical facet of effective Defence Healthcare Engagement (DHE), which includes the use of defence medical assets in support of capacity-building overseas. The analytical process described may form the basis of DHE planning. It may have even greater importance in the near future as countries review national resilience and global health diplomacy after the COVID-19 crisis.
\end{abstract}

\section{INTRODUCTION}

The range of healthcare providers in a country's health economy should be considered as part of a Defence Healthcare Engagement (DHE) plan. ${ }^{1}$ This paper examines the generic characteristics and unique aspects of the security sector compared with other health service providers. The 2014 West African Ebola crisis is a good case example of civil-military inter-relationships between national and international health providers. ${ }^{2}$ This led to wider discussion around medical humanitarianism, global health security ${ }^{3}$ and the contribution of security sector health systems to global health. ${ }^{4}$ Currently, armed forces health services are a prominent feature of the responses of individual

${ }^{1}$ Conflict and Health Research Group, King's College London, London, UK

${ }^{2}$ Academic Department of Military Emergency Medicine, Royal Centre for Defence Medicine, Birmingham, UK

Correspondence to Professor Martin Bricknell, Conflict and Health Research Group, King's College London - Strand Campus, London WC2R 2LS, UK; profmartinmilmed@gmail.com governments to the current COVID-19 crisis. $^{5}$

The United Nations Sustainable Development Goal (SDG) 3-ensure healthy lives and promote well-being for all at all ages-includes target 3.8: Universal Health Coverage (UHC). ${ }^{6}$ SDG 16-promote just, peaceful and inclusive societies-covers the principles of the security sector reform, including the development of effective, accountable and transparent security institutions, and building capacity at all levels to prevent violence and combat terrorism and crime. ${ }^{7}$ In some countries the security sector may represent a disproportionate component of government spending compared with social protection. Benefits provided by the security health system to its dependent population may exceed the standard available to other citizens of a state. ${ }^{8}$ Therefore, the role and transformation of a state's security health system within UHC sits at the interface of SDG 3 and SDG 16. Civil-security relationships are a critical facet of DHE and wider health sector development, especially as countries review national resilience and global health diplomacy after the COVID-19 crisis.

\section{SECURITY SECTORS}

The term 'security sector' covers a complex network of institutions, forces and services that contribute to the security of a state and its people. ${ }^{9}$ It includes those managed at the national level, such as the armed forces, intelligence services, police, judiciary services (the administration of law and the penal system) and border control. There may be other government-funded security institutions such as a 'presidential guard', or with specific mandates such as a gendarmerie for armed internal security. ${ }^{10}$ Some may be provided at a regional or local level, particularly police services and prisons. In many countries, there are also non-government providers of security: formal private security companies, informal community groups, militias and personally employed guards. Therefore, the picture is of civil-security relationships, not solely civil-military ones. The potential range of security services and forces in a country is shown in Figure 1.
ROLES FOR SECURITY SECTOR HEALTH SYSTEMS

Beneficiaries

Access to health services can be a significant benefit of employment that may extend to other beneficiaries: family members, retirees from service, veterans of previous conflicts, personnel with health conditions related to employment in the security forces, civilian (non-uniformed) employees, non-security civilians with beneficial access (e.g. other public sector workers or elites) or general civilians (with or without copayment to the institution or privately to individual doctors). Prisoners are a specific population that requires healthcare provision from several parts of the security system, for example, the intelligence services for those people held for investigation, the police services for those held until admission to prison, the armed forces for prisoners of war or personnel within the military justice system, and the probation system for prisoners after their release.

\section{Clinical services}

The provision of occupationally orientated, general health services is the main function of a comprehensive security health system. ${ }^{11}$ The nature of employment may place significant physical and psychosocial demands on employees, mandating occupational health assessments on recruitment, during employment, after a period of ill health and on departure from service. In addition, health promotion (e.g. physical fitness, mental health awareness and first aid training), preventive medicine to protect the workforce from the hazards of the security environment (eg, immunisation programmes, environmental medicine), and medical advice to senior executive and human resources specialists must all be provided.

The nature and extent of general health services will be dependent on the wider organisation of public health services. Often the needs of the non-uniformed beneficiaries determine the range of clinical services to be provided, such as maternal care, paediatrics, general medical and surgical services, geriatrics, mental health, and tertiary services such as cancer or cardiology. These services may exceed provision in the wider public health system to other citizens.

Personnel within security services may be at greater risk of specific illnesses or injuries than the general population, necessitating specially trained medical systems. Uniformed members of the armed forces 


\section{Security Services and Forces}

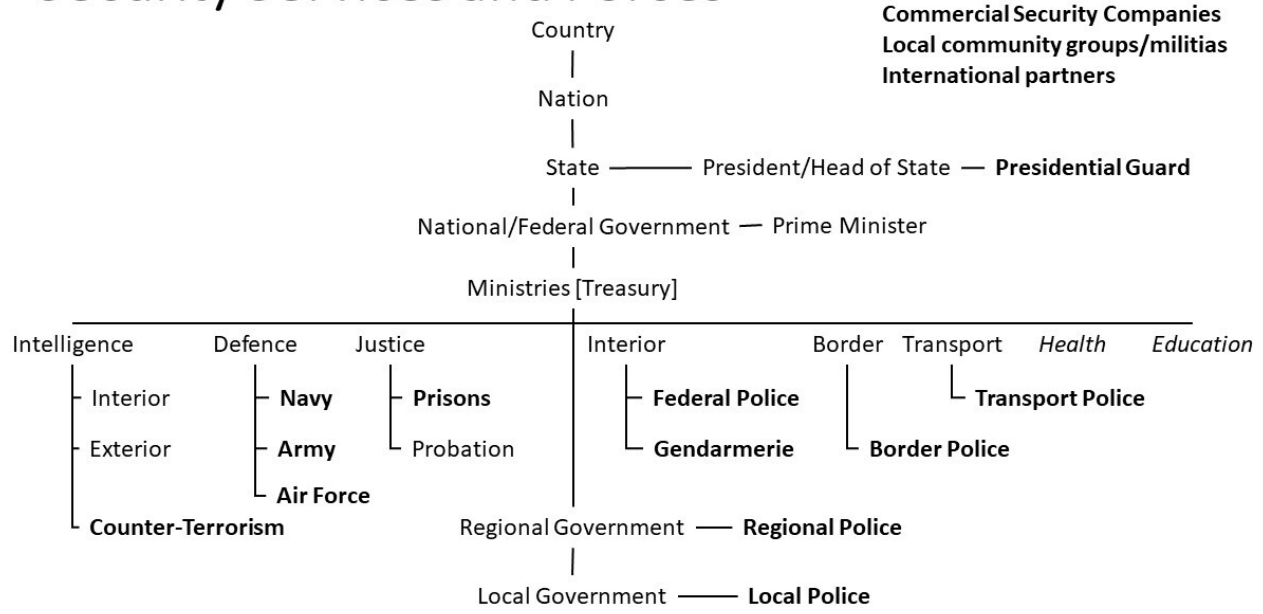

Non-state:

Commercial Security Companies

Local community groups/militias

International partners
Local Government —— Local Police

Figure 1 Security services and forces.

require trauma care from point of injury through to rehabilitation and recovery. These systems conduct field operations in conflict environments and so uniformed military healthcare personnel require military skills alongside their professional healthcare skills. When not on military operations, these personnel may support the delivery of general health services. Internal security forces conducting counterterrorism or public order operations will also need point of injury care and evacuation to hospital (e.g. 'public order medics' in UK policing). ${ }^{12}$ This might be provided as a capability within the security force or as support from another security force (eg, the armed forces), or the civilian health services may have personnel specifically trained and equipped to operate in this environment (eg, UK NHS Hazardous Area Response Teams ${ }^{13}$ ). Depending on the conflict, the internal security threat may extend to the personal life of members of the security forces such that they need to live within a secure environment. This threat can extend to healthcare facilities and so security personnel may need protection as patients inside secure hospitals (e.g. the military wing of Northern Ireland's Musgrave Park Hospital during the Troubles ${ }^{14}$ ). This issue alone can justify a health system for security forces personnel that is separate from the wider public system.

System-level organisation and interfaces While designed to provide for its dependant population, the security sector health system also provides extra healthcare capacity that can support wider government objectives, for example, as a strategic reserve of government hospital capacity in times of crisis. It can also be the only part of the governmentcontrolled health system that is designed to deploy people and facilities from their normal place of work, projecting capabilities such as medical evacuation (ambulances, helicopters, aeroplanes) and field hospitals as part of an integrated response to natural disasters. Routinely, mechanisms for cross-sectoral collaboration might include arrangements for reciprocal support between security services in order to maximise efficiency and reduce duplication of health services. Beyond clinical services, this might extend to research, education and training of the workforce, pharmaceutical and medical device procurement, and employment through a working life.

\section{Individual security services}

Specific components of the security sector tend to share some generic characteristics across different nations.

\section{Armed forces}

Almost universally, armed services have a separate health system from the government civilian system. A recently published concept, the defence healthcare cycle, describes a framework for analysing the clinical services provided by a military health system covering both operational healthcare and firm base (garrison/ community services and definitive (secondary) healthcare). ${ }^{11}$ The military health system often has additional institutions that provide training and education to healthcare personnel, conduct research on military medical subjects, and provide specialist occupational, mental health and rehabilitation services.

\section{Police services}

International comparisons between nations' police systems are a relatively neglected area of political science. ${ }^{15}$ Information on police health services is also difficult to access with no international database of police health systems and few dedicated medical journals. Structurally there is a balance between control at a national and regional level. As an example, in the UK, the British Transport Police, the Civil Nuclear Constabulary and the Ministry of Defence Police are national services. Territorial policing in the UK is organised by metropolitan and county councils. This international variation also includes the provision of health services to police personnel. In the UK there are no separate government general health services for the police, although every force has an occupational health service. Additionally, there are two police treatment centres ${ }^{16}$ and a police rehabilitation centre ${ }^{17}$ that are funded through charities. Internationally, many nations have dedicated police hospitals that operate separately from both the armed forces and the public health system (eg, Ghana, ${ }^{18}$ Thailand ${ }^{19}$ and $\mathrm{Nepal}^{20}$ ). A police service may also contribute to other domains of public health, including emergency first aid response for trauma and mental health, drugs and substance misuse control, and sexual health. ${ }^{21}$

\section{Penal systems}

The responsibility of governments for the provision of healthcare to prisoners within the penal system has become increasingly recognised. The World Prison Brief provides a database and analysis of prison systems across the world. ${ }^{22}$ The WHO 
European Health in Prisons Project ${ }^{23}$ has developed standards for the provision of primary care services within jails based on the unique health needs of prisoners. The Worldwide Prison Health Research \& Engagement Network ${ }^{24}$ has been established as a collaborative research forum to establish evidence base and capacitybuilding initiatives to improve the health of people in prison. While small, it is important that this group is considered within the wider domain of global health.

\section{Miscellaneous security services' health systems}

Individual countries may make further provision for health services for other populations within their security system. This may apply to specific heads of state. In the UK, the 'medical royal household' is formed from eminent clinicians in the UK health system, including members of the Defence Medical Services. ${ }^{25}$ In the USA, the White House Medical Unit provides care for White House staff and visitors with hospital care provided by the US military health system. ${ }^{26}$ In other countries the senior leadership may be protected by an independent security institution, such as a 'presidential guard', which may have its own separate health system (eg, the Saudi Arabia National Guard ${ }^{27}$ ), or elites may have their own clinics (eg, Russia ${ }^{28}$ ). Some countries have specialist armed 'gendarmeries' to provide internal national security and these might have their own health system (eg, the Indian National Security Guard $^{29}$ or the Carabinieri in Italy ${ }^{30}$ ).

\section{POTENTIAL ANALYSIS FOR DEFENCE HEALTH ENGAGEMENT}

For a specific country, the first level of analysis would be to identify all the providers of healthcare to the individual components of the security sector to determine the relative scale of the security sector's health system compared with all other providers of health services, including understanding the extent of the beneficiary populations. The next level of analysis would quantify the health capabilities present within each component, including those that are essential national assets, for example, the deployable medical system of the armed forces, national disaster response capabilities, prisoner healthcare, government research capabilities in aviation medicine or biological defence, and educational institutions teaching trauma care or remote medicine. The third level would capture the range of general health services supplied by each health provider in order to identify those that are common between providers and those that are unique (eg, maternity services vs decompression chambers). The final level would be to understand the organisational motivations and behaviours that facilitate the evolution of the system or act as barriers to change.

Evidence for these analyses might be available from public sources, although it is most likely they will be in the official language of the country case study. The quality and completeness of public information provided will vary by security actor and so is unlikely to be fully representative. Collaborative partners may provide additional evidence from internal documents, though semistructured interviews with key informants may also be required.

\section{CONCLUSIONS}

This paper has outlined the structure of a country's security system, and the potential beneficiaries, clinical services and macro-organisation of each security services' health system. It also considers their potential contribution to wider government health services and crisis response. Analysing the context and operating environment of a partner nation's health system, and the structure of the country's security sector health system, would support the mission analysis for DHE activities. The products could have high utility for civil-military collaboration between policymakers and practitioners involved in health systems strengthening and development, as well as for those involved in security sector reform. This will be especially important as part of the reviews of international and national responses to the COVID-19 pandemic.

Twitter Martin Bricknell @MartinBricknell and S Horne @TriageMonkey

Contributors MB and SH equally conceived, drafted and guarantee this paper.

Funding This study was funded by the UK Research and Innovation GCRF Research for Health in Conflict developing capability, partnerships and research in the Middle and Near East programme (R4HC-MENA).

Competing interests $\mathrm{SH}$ is the Acting Assistant Head of the Academic Centre for Defence Healthcare Engagement.

Patient consent for publication Not required. Provenance and peer review Not commissioned; externally peer reviewed.

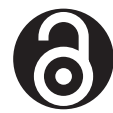

\section{OPEN ACCESS}

Open access This is an open access article distributed in accordance with the Creative Commons Attribution
Non Commercial (CC BY-NC 4.0) license, which permits others to distribute, remix, adapt, build upon this work non-commercially, and license their derivative works on different terms, provided the original work is properly cited, appropriate credit is given, any changes made indicated, and the use is non-commercial. See: http:// creativecommons.org/licenses/by-nc/4.0/.

(C) Author(s) (or their employer(s)) 2020. Re-use permitted under CC BY-NC. No commercial re-use. See rights and permissions. Published by BMJ.

\section{Check for updates}

To cite Bricknell M, Horne S. BMJ Mil Health Epub ahead of print: [please include Day Month Year]. doi:10.1136/bmjmilitary-2020-001607

Received 15 July 2020

Revised 23 August 2020

Accepted 26 August 2020

BMJ Mil Health 2020:0:1-4.

doi:10.1136/bmjmilitary-2020-001607

\section{ORCID iDs}

Martin Bricknell http://orcid.org/0000-0002-5080-0095

S Horne http://orcid.org/0000-0002-5098-7996

\section{REFERENCES}

1 Bricknell M, Hinrichs-Krapels S, Ismail S, et al. Understanding the structure of a country's health service providers for defence health engagement. $B M J$ Mil Health 2020.

2 Kamradt-Scott A, Harman S, Wenham C, et al. Civilmilitary cooperation in Ebola and beyond. The Lancet 2016;387:104-5

3 Harman S, Wenham C. Governing Ebola: between global health and medical humanitarianism. Globalizations 2018;15:362-76.

4 Michaud J, Moss K, Licina D, et al. Militaries and global health: peace, conflict, and disaster response. Lancet 2019:393:276-86.

5 NATO's Response to the COVID-19 Pandemic. North Atlantic Treaty organisation, 2020. Available: https:// www.nato.int/nato_static_fl2014/assets/pdf/2020/5/ pdf/200525-factsheet-COVID-19_en.pdf [Accessed 15 Jun 2020].

6 SDG 3: Ensure healthy lives and promote wellbeing for all at all ages. World health organisation. Available: https://www.who.int/sdg/targets/en/ [Accessed 14 Jun 2020].

7 Sustainable development goal 16 . United nations and the rule of law. Available: https://www.un.org/ ruleoflaw/sdg-16/ [Accessed 14 Jun 2020].

8 Magnezi R, Dankner R, Shani M, et al. Comparison of health care services for career soldiers throughout the world. Mil Med 2005:170:995-8.

9 UN General Assembly Resolution. S/RES/2151. 2014 The maintenance of international peace and security: security sector reform: challenges and opportunities. Available: https://undocs.org/S/RES/2151(2014) [Accessed 14 Jun 20].

10 Gendarmeries and constabulary-type police. SSR Backgrounder Series. DCAF - Geneva Centre for Security Sector Governance, 2019. Available: https:// www.dcaf.ch/sites/default/files/publications/ documents/DCAF_BG_15_Gendarmeries $\% 20$ and $\%$ 20constabulary-type\%20police_0.pdf [Accessed 14 Jun 2020].

11 Bricknell M, Cain P. Understanding the whole of military health systems: the defence healthcare cycle. The RUSI Journal 2020;65:40-9.

12 Public Order Medic. College of policing. Available: https://profdev.college.police.uk/professional-profile/ public-order-medic/ [Accessed 14 Jun 2020].

13 Ambulance Hazardous Area Response Team. Available: http://ambulancehart.org.uk/ [Accessed 14 Jun 2020] 
14 Moffat WC. British forces casualties in Northern Ireland. BMJ Military Health 1976;122:3-8.

15 Calaresu M, Tebaldi M. The comparative analysis of European national police systems: a theoretical and methodological proposal for a new research agenda. Police Practice and Research 2019;2:1-15.

16 The police treatment centres. Available: https://www. thepolicetreatmentcentres.org/ [Accessed 14 Jun 2020].

17 The police rehabilitation centre. Flint house. Available: https://www.flinthouse.co.uk/ [Accessed 14 Jun 2020].

18 Ghana Police Service. Police Hospital Accra. Available: https://police.gov.gh/en/index.php/police-hospitalaccra/ [Accessed 14 Jun 2020].

19 The police Hospital. Available: http://www. policehospital.org/content/home.php [Accessed 14 Jun 2020].
20 Nepal police Hospital. Available: https://nph nepalpolice.gov.np/ [Accessed 15 Jun 20].

21 van Dijk AJ, Herrington V, Crofts N, et al. Law enforcement and public health: recognition and enhancement of joined-up solutions. Lancet 2019:393:287-94.

22 World prison brief. Available: https://www. prisonstudies.org/ [Accessed 14 Jun 2020].

23 Gatherer A, Moller L, Hayton P. The world Health organization European health in prisons project after 10 years: persistent barriers and achievements. Am J Public Health 2005;95:1696-700.

24 Worldwide Prison Health Research and Engagement Network. Available: https://wephren.tghn.org/ [Accessed 14 Jun 2020].

25 Medical Household. Available: https://en.wikipedia. org/wiki/Medical_Household [Accessed 14 Jun 2020].
26 White house medical unit. Available: https://en. wikipedia.org/wiki/White_House_Medical_Unit [Accessed 14 Jun 20].

27 Ministry of National Guard - Health Affairs. Available: https://ngha.med.sa/English/Pages/default.aspx [Accessed 14 Jun 2020].

28 Reiter S, Miledin P. VIP treatment: Special health clinic planned for Putin's elite officials, 2017. Available: https://www.reuters.com/investigates/ special-report/russia-kremlin-hospital/ [Accessed 14 Jun 2020].

29 National security guard, India. Available: https://nsg. gov.in/search/node/hospital [Accessed 14 Jun 2020].

30 Italian Republic. Worldwide military medicine. Available: https://military-medicine.com/almanac/67italian-republic.html [Accessed 14 Jun 2020]. 